\title{
Factors Affecting Immigrant Patients Against Utilization of Health Services at Tamalanrea Health Center
}

\author{
Nurul Qalbi R*1, Indar ${ }^{2}$, Rahmatiah ${ }^{3}$ \\ ${ }^{1}$ Magister of Public Health Sciences, Hasanuddin University, Makassar, Indonesia \\ 2 Department of Administration and Health Policy, Hasanuddin University, Makassar, Indonesia \\ ${ }^{3}$ Department of Economics, Hasanuddin University, Makassar, Indonesia \\ Email : nurulqalbirrr@yahoo.co.id
}

\begin{abstract}
Good health care is a community need and is often a measure of development success. The utilization of health service units is still relatively low, although the Puskesmas continue to try to bring health services closer to immigrants. This shows that the lack of confidence of immigrant patients in the health services provided by health workers so that immigrant patients prefer to be referred and continue treatment at the hospital. The purpose of this study is to analyze the factors that influence immigrant patients on the utilization of health services. This research was conducted at Tamalanrea Public Health Center in Makassar City from July-August 2019. The population in this study was 154 people based on data in Tamalanrea Health Center in the last 6 months while the sample in this study was 59 people. Analysis of the data used in this study includes univariate and bivariate analysis stages using multiple regression tests using SPSS version 10 . The results of this study indicate that (1) Age has no influence on the utilization of health services, gender has an influence on the utilization of health services in Tamalanrea Health Center ; (2) There is an influence of facilities, and trust in the use of health services with the respective $p$-value: facilities $p=0.015$ and trust $p=0.004$. While knowledge has a value of $p=0.665$ so that it does not influence the utilization of health services at the Tamalanrea Health Center. The important role of the immigration detection house agency is to help promote and convince immigrants or foreign refugees that first-rate health services can provide the best health services and cure their sickness.
\end{abstract}

Keywords : Health Utilization, Immigrant, Health Center, Knowledge, Facilities, Trust.

\section{INTRODUCTION}

Good health services are a community need and are often a measure of development success (Rumengan et al., 2015). Individual needs to utilize health services are directly affected by psychological variables which include: tastes, sick-health perceptions, expectations, assessments of providers; and individual characteristics including age, sex, level of education and type of work. Indirect factors are influenced by socio-economic and culture (Damayanti et al., 2017).

Utilization of health services is the use of service facilities provided either in the form of outpatient care, inpatient care, home visits by health workers or other forms of service utilization based on availability and continuity of services, community acceptance and fairness, easily reached by the community, affordable , and quality (Tasya and Andriany, 2016). 
Utilization of health services at the health center level has several factors that influence it, namely consumer factors in the form of: education, livelihoods, knowledge and perceptions of patients; organizational factors such as: availability of resources, affordability of service locations, and social access; and service provider factors including: health worker behavior (Abdullah et al., 2017).

In the current era of globalization, ethical principles need to be maintained because without ethics and without being strengthened by the law, one human can be regarded as a rival by others. The field of health services must be based on ethical and legal principles as a result of the arising of human greed, which in turn creates conflict between patients with health workers and among other health workers (Indar, 2017).

Immigrants or refugees are refugees who cannot and will not likely return to their home countries due to fears of life-threatening situations in matters such as race, religion, citizenship, membership in social groups, or political matters (Collyer, 2010). But sometimes the problems are growing so that immigrants have no choice but to try to enter a country illegally. Also, related to the right to health and education, as well as residence support from related parties often do not meet the needs of refugees. For this reason, IOM's role as an international organization is very much needed to establish cooperation with destination countries of migrants while ensuring that the rights of these migrants can still be fulfilled well (Nst, 2018).

Immigrants have some special needs for certain types of health problems because of the prevalence of the disease and the healthy environment in the country of origin. For example, the rate of tuberculosis is much higher among immigrants than among native birth populations (for example, in 2010, 18.1\% for foreign births vs $1.8 \%$ for US births, especially among foreigners born in Asia and the Islands. Pacific, $33.2 \%$, and blacks born abroad, 26.2\%; Centers for Disease Control and Prevention Asthma rates are also higher among foreigners born than those born in the US (Hwang, 2016).

Tamalanrea Health Center is one of the health centers that cooperates with IOM in providing health services to immigrants who come for treatment. The immigrants referred to in this study are foreign refugees who came to Indonesia due to various conflicts in their country. Also, the Tamalanrea Health Center has a large enough working area in dealing with immigrant patients, consisting of 4 community houses or shelters and immigration detention centers. In the working area of Tamalanrea Health Center there are 4 Guesthouse points, namely in $155 \mathrm{~A}$ as many as 45 people, $155 \mathrm{~B}$ as many as 58 people, $155 \mathrm{C}$ as many as 22 and $155 \mathrm{D}$ as many as 77 people. So the total number in the working area of Tamalanrea Health Center is 202 people. The origin of immigrants in the Tamalanrea Health Center area comes from various countries, namely: Afghanistan, Somalia, Ethiopia, Iran, Myanmar, Sudan, and Pakistan. According to Anderson, 3 factors influence a person's behavior in utilizing health services, namely predisposing characteristics (education, employment, ethnicity), supporting characteristics (enabling), namely facilities, infrastructure and needs characteristics (Wahyuni, 2012).

Based on preliminary data obtained from Tamalanrea Health Center, the number of visits of immigrant patients in the last 6 months, namely: December 2018 as many as (20 people); January 2019 (33 people); February 2019 as many as (31 people); March 2019 (31 people); April 2019 as many as (20 people); May 2019 (11 people). From the above data it can be 
concluded that the number of patient visits during the past 6 months fluctuated and in the last 2 (two) months dropped dramatically. In addition the number of immigrant patient referrals in the last 6 months from data obtained at the Tamalanrea Health Center are: December 2018 (15 people); January 2019 (16 people); February 2019 (19 people); March 2019 (12 people); April 2019 (19 people); May 2019 (8 people). From the above data, it can be concluded that half of the total number of patient visits that come for treatment has been given a referral to the hospital with the most dominant reason at the request of immigrant patients themselves (Puskesmas Tamalanrea, 2019). Meanwhile, based on the number of diseases that can be served at the Puskesmas 155 types of diseases can be handled/served by the Puskesmas. But in fact, the number of referrals for immigrant patients who are issued every month is increasing while the type of disease referred can be treated/served at the Tamalanrea Health Center.

The utilization of health service units is still relatively low, although the Puskesmas continue to try to bring health services closer to immigrants. This shows that the lack of immigrant patients' trust in the health services provided by health workers in the Tamalanrea Health Center so that immigrant patients prefer to be referred and continued treatment at the Hospital. From the description above, it appears that the utilization of health services in Puskesmas by immigrant patients is still lacking, although physically the health facilities in Puskesmas Tamalanrea can handle 155 types of diseases. This may occur because the available service facilities are not following the wishes of the immigrant community or the lack of confidence of immigrant patients in the services provided. The purpose of this study was to analyze the factors that influence immigrant patients on the utilization of health services in the Tamalanrea Health Center.

\section{METHODS AND MATERIAL}

This research was conducted in August 2019 at the Tamalanrea community health center, Makassar. Based on data at the Tamalanrea Health Center in the past 6 months, the population in this study was 154 people. The criteria for determining the sample were patients visiting community health centers more than once so as many as 59 people were obtained. The sampling technique in this study used purposive sampling. Data collection is done using observation, interviews, and documentation. Analysis of the data used in univariate and bivariate analysis using multiple regression tests with the program SPSS version 10 .

\section{RESULTS AND DISCUSSION}

\section{Univariate Analysis}

Univariate analysis was performed to determine the frequency distribution of each study variable both the dependent variable and the independent variable. The results of the univariate analysis in this study are as follows.

a. Age Group. Is a group of values based on the age of the respondents with the interval used is 10 years which can be seen in Table 1 .

Table 1. Distribution of Respondents by Age Group for Immigrant Patients at the Tamalanrea Health Center in 2019

\begin{tabular}{ccc}
\hline Age (year) & (n) & $\%$ \\
\hline $15-25$ & 20 & 33,9 \\
$26-36$ & 26 & 44,1 \\
$37-47$ & 11 & 18,6 \\
$48-58$ & 2 & 3,4 \\
\hline Amount & 59 & 100,0
\end{tabular}

Source: primary data that has been processed, 2019 
Table 1 shows that of the 59 respondents based on the age of the respondents, the most were in the 2636 years age group, which were 26 people $(44.1 \%)$ and the least number of respondents in the 48-58 year age group, namely as many as 2 people (3, $4 \%$ ). Based on the results of the study in table 1 shows that most age groups are in the age group 26-36 years as many as 26 people (44.1\%). Age can affect someone in the utilization of health services. The older a person is, the more critical and understanding the importance of service utilization.

b. Gender. The distribution of respondents by sex can be seen in Table 2 .

Table 2. Distribution of Respondents by Gender Immigrant Patients in the Tamalanrea Health Center in 2019

\begin{tabular}{ccc}
\hline Gender & (n) & $(\%)$ \\
\hline Man & 54 & 91,5 \\
Woman & 5 & 8,5 \\
\hline Amount & 59 & 100,0 \\
\hline
\end{tabular}

Source: primary data that has been processed, 2019

Table 2 shows that of the 59 respondents based on the most sex, there were 54 male respondents (91.5\%) while the least female respondents were 5 people $(8.5 \%)$.

c. Latest Education. The last education is the last level of education obtained by respondents. The distribution of respondents based on their latest education can be seen in Table 3 .

Table 3. Distribution of Respondents Based on the Latest Education of Immigrant Patients in Tamalanrea Health Center in 2019.

\begin{tabular}{|c|c|c|}
\hline $\begin{array}{c}\text { Last } \\
\text { Education }\end{array}$ & (n) & (\%) \\
\hline $\begin{array}{c}\text { Not Finished } \\
\text { primary } \\
\text { school }\end{array}$ & 4 & 6,8 \\
\hline $\begin{array}{l}\text { Primary } \\
\text { school }\end{array}$ & 7 & 11,9 \\
\hline $\begin{array}{l}\text { Junior high } \\
\text { school }\end{array}$ & 17 & 28,8 \\
\hline $\begin{array}{c}\text { Senior high } \\
\text { school }\end{array}$ & 26 & 44,1 \\
\hline College & 5 & 8,5 \\
\hline Amount & 59 & 100,0 \\
\hline
\end{tabular}

Source: primary data that has been processed, 2019

Table 3 shows that of the 59 respondents based on their most recent education the most were high school / equivalent categories of 26 people $(48.0 \%)$ and the smallest number of respondents were elementary school as many as 4 people $(2.0 \%)$. Ha NTH et al (2012) in a study (Rushender et al., 2017) stated that health services in Vietnam found that education of household heads and the number of sick people in the family did not have a significant influence on the utilization of public health services (or) health services. Likewise in a study conducted by Rushender (2017) stated that the education factor of household heads did not show a significant relationship in PHC utilization to the distance traveled (Rushender et al., 2017).

d. Country of Origin. The distribution of respondents by country of origin can be seen in Table 4. 
Table 4. Distribution of Respondents by Country of Origin of Immigrant Patients at the Tamalanrea Health Center in 2019.

\begin{tabular}{ccc}
\hline $\begin{array}{c}\text { Country of } \\
\text { origin }\end{array}$ & (n) & (\%) \\
\hline Afghanistan & 53 & 89,8 \\
Euthopia & 1 & 1,7 \\
Myanmar & 2 & 3,4 \\
Sudan & 3 & 5,1 \\
\hline Amount & 59 & 100,0 \\
\hline
\end{tabular}

Source: primary data that has been processed, 2019

Table 4 shows that of the 59 respondents by country of origin the most were from Afghanistan, namely as many as 53 people $(89.8 \%)$ and the smallest number of respondents originating from Ethiopia, namely as many as 1 people $(1.7 \%)$.

e. Length of stay in Makassar. The distribution of respondents based on length of stay in Makassar can be seen in Table 5

Table 5. Distribution of Respondents Based on Length of Stay of Immigrant Patients at Tamalanrea Health Center in 2019

\begin{tabular}{ccc}
\hline $\begin{array}{c}\text { Long stay in } \\
\text { Makassar (Year) }\end{array}$ & $(\mathbf{n})$ & $(\%)$ \\
\hline 1 & 4 & 6,8 \\
2 & 10 & 16,9 \\
3 & 5 & 8,5 \\
4 & 7 & 11,9 \\
5 & 17 & 28,8 \\
6 & 11 & 18,6 \\
7 & 5 & 8,5 \\
\hline Amount & 59 & 100,0 \\
\hline
\end{tabular}

Source: primary data that has been processed, 2019
Table 5 shows that of the 59 respondents based on length of stay the most were for 5 years as many as 17 respondents $(28.8 \%)$ and the least number of respondents was for 1 year as many as 4 people (6.8\%).

\section{f. Frequency Distribution of Research Variables}

In this study, there are five independent variables namely Knowledge, facilities, attitudes and behavior of health workers, trust and length of stay in Makassar, which will be seen as influencing the dependent variable, namely the utilization of health services. The frequency distribution of research variables can be seen in Table 6 .

Table 6. Based on the results of the study, the frequency distribution for variable utilization of health services

\begin{tabular}{ccc}
\hline $\begin{array}{c}\text { Service } \\
\text { utilization }\end{array}$ & (n) & (\%) \\
\hline $\begin{array}{c}\text { To take } \\
\text { advantage of } \\
\text { Haven't utilized }\end{array}$ & 45 & 76,3 \\
\hline Amount & $\mathbf{5 9}$ & 23,7 \\
\hline
\end{tabular}

Source: primary data that has been processed, 2019

Based on Table 6 shows that of 59 respondents in Tamalanrea Health Center, 45 respondents (76.3) had utilized health services and 14 respondents (23.7\%) had not utilized health services. Health service utilization was significantly higher among refugees, who also reported greater service needs than native immigrants (Elsouhag et al., 2015).

Based on the research results obtained by the frequency distribution for knowledge variables can be seen in Table 7 .

Table 7. Distribution of Respondents Based on Knowledge of Immigrant Patients on Utilization of Health Services at Tamalanrea Health Center 


\begin{tabular}{clc}
\hline Knowledge & (n) & (\%) \\
\hline Enough & 35 & 59,3 \\
Less & 24 & 40,7 \\
\hline Amount & $\mathbf{5 9}$ & $\mathbf{1 0 0 , 0}$ \\
\hline
\end{tabular}

Source: primary data that has been processed, 2019

Based on Table 7 shows that of 59 respondents in Tamalanrea Health Center, 35 respondents (59.3\%) had sufficient knowledge of the utilization of health services and as many as 24 respondents (40.7\%) lacked knowledge of the utilization of health services.

g. Facilities : Based on the research results, the frequency distribution for facility variables can be seen in Table 8. Table 8 Distribution of Respondents Based on Facilities towards Utilization of Health Services at Tamalanrea Health Center.

Table 8. Distribution of Respondents Based on Facilities towards Utilization of Health Services at Tamalanrea Health Center

\begin{tabular}{ccc}
\hline Facilities & (n) & (\%) \\
\hline Complete & 34 & 57,6 \\
Less complete & 25 & 42,4 \\
\hline Amount & $\mathbf{5 9}$ & $\mathbf{1 0 0 , 0}$ \\
\hline
\end{tabular}

Source: primary data that has been processed, 2019

Based on Table 8, shows that of 59 respondents in Tamalanrea Health Center, 34 respondents (57.6\%) stated that complete health facilities were used for health services and 25 respondents (42.4\%) stated that health facilities were incomplete in the utilization of health services.

Table 9. Distribution of Respondents Based on Trust in the Utilization of Health Services at Tamalanrea Health Center

\begin{tabular}{clc}
\hline Trust & (n) & (\%) \\
\hline Believe & 31 & 52,5 \\
Lack of trust & 28 & 47,5 \\
\hline Amount & 59 & 100,0
\end{tabular}

Source: primary data that has been processed, 2019

Based on Table 9 shows that of the 59 respondents in Tamalanrea Health Center, 31 respondents (52.5\%) expressed confidence in the utilization of health services and 28 respondents (47.5\%) expressed less confidence in the utilization of health services.

\section{Bivariate Analysis}

Bivariate analysis was carried out to analyze the relationship between the independent variables (knowledge, facilities, and beliefs) and the dependent variable (utilization of health services at the Tamalanrea Health Center) by cross-tabulating using the chi-square test with $\mathrm{p}<\alpha(0.05)$ the research hypothesis (Ho) is rejected, meaning that there is a relationship between the independent variable and the dependent variable.

Table 10. Effect of Knowledge with Utilization of Health Services at Tamalanrea Health Center

\begin{tabular}{|c|c|c|c|c|c|c|c|}
\hline \multirow{3}{*}{ Knowledge } & \multicolumn{4}{|c|}{ Utilization of health services } & & & \multirow{3}{*}{$p$} \\
\hline & \multicolumn{2}{|c|}{ To take advantage of } & \multicolumn{2}{|c|}{ Haven't utilized } & \multicolumn{2}{|c|}{ Amount } & \\
\hline & $\mathbf{n}$ & $\%$ & $\mathbf{n}$ & $\%$ & $\mathbf{n}$ & $\%$ & \\
\hline Enough & 26 & 74,3 & 9 & 25,7 & 35 & 100,0 & 0,665 \\
\hline Less & 19 & 79,2 & 5 & 20,8 & 24 & 100,0 & \\
\hline Amount & 45 & 76,3 & 14 & 23,7 & 59 & 100,0 & \\
\hline
\end{tabular}

Source: primary data that has been processed, 2019 
Table 10 shows that out of 35 respondents belonging to sufficient knowledge 26 respondents (74.3\%) had utilized health services and 9 respondents (25.7\%) had not utilized health services. While of the 24 respondents who lack knowledge, 19 respondents (79.2\%) who have utilized health services and as many as 5 respondents (20.8\%) who have not utilized health services at the Tamalanrea Health Center. Statistical test results obtained the value of $\mathrm{p}=0.665$ because the value of $p>\alpha=0.665<0.05$ then Ho is accepted, this means that there is no relationship between the knowledge variable and the utilization of health services in the Tamalanrea Health Center. The results of this study are in line with the results of research conducted by (Karman and Saptaputra, 2017) which states that there is no significant relationship between knowledge and the utilization of health services in coastal communities in Bungie Permai Village Tinanggea District Konawe Selatan District based on the Chi-Square Test obtained $\rho=0.231>(\alpha$ $=0.05)$ which means that $\mathrm{HO}$ is accepted or $\mathrm{Ha}$ is rejected. Whereas the research (Pratiwi and Wahyono, 2017) shows the results of a bivariate analysis that knowledge has a relationship with the utilization of health services with a p-value of 0,000 $(\mathrm{p}<0.05)$. And the results of multivariate analysis show that good knowledge influences students in the utilization of health services in Puskesmas Unnes ( $\mathrm{p}=$ 0,000; $\exp (B)=11,341 ; 95 \% C I=4,479-28,719)$. Knowledge is the dominant variable that is very important in the formation of one's actions.

Based on research (Marnah et al., 2016) the results show that the more understood the respondent related to health services, the respondent can determine the response/attitude towards the utilization of health services. This study was strengthened by the results of the study (Yaya et al., 2017) which showed that respondents with good knowledge about health services were 0.816 times more likely to utilize health services $(\mathrm{p}=0.012)$ compared to respondents who had poor knowledge. Respondents' knowledge about seeking treatment may be influenced by many factors, such as experience and information facilities. Knowledge is not only obtained formally but also through experience, besides knowledge is also obtained through available information facilities such as the internet, radio, leaflets, and so on. Research in the field also produced information that many students did not know about Puslakes because they had never obtained information or socialization about the existence and function of Puslakes at Semarang State University. This shows that the low utilization of Puslakes by students is due to the low knowledge of students about Unnes Puslakes (Pratiwi and Wahyono, 2017).

The level of individual knowledge will greatly affect the awareness to participate in an activity and have an impact on behavior. But when analyzed further the process of formation of awareness is not only influenced by knowledge. Knowledge alone is not enough to make someone change his behavior. Change or adoption of behavior is a complex process and requires a relatively long time. In theory, a change in behavior a person accepts or adopts a new behavior in his life through three stages, namely knowledge, that is, before someone adopts a behavior (new behavior), he must know in advance what the meaning or benefit of the behavior is for himself or his family, an attitude that is after someone knows the stimulus or object, the next process will assess or behave towards the stimulus or health object, practice or action that is after someone knows the stimulus or health object, then conducts an assessment or opinion of what they know or react to (Notoatmodjo, 2003). 
The results of this study are not in line with the results of research conducted by (Hasim, 2006) in (Rachmawati and Amir, 2014) in Kontunaga Village, Kontunaga District, indicating that the community knows whether or not what is and how the services provided at puskesmas are due to the lack of information they receive the function and role of the pusskesmas as well as the existing health service procedures at the puskesmas most of the respondents did not know the type of service and puskesmas service procedures as well as the community's perception that the puskesmas was the last place of treatment if it could not be treated by a shaman or self-medicated. Likewise, research conducted by (Wibowo et al., 2019) states that knowledge has a significant relationship to the utilization of health services based on the results of the Chi-square test ( $\mathrm{p}$ value $<0.05)$ This means that $\mathrm{Ho}$ is rejected $\mathrm{Ha}$ accepted.

Based on research conducted by (Singal et al., 2019) with the test results of the relationship between knowledge and the use of Puskesmas by the Kima Bajo village community, the Chi-square statistical test results showed a value of $\mathrm{p}<0.05$ so it can be concluded that there is a relationship between knowledge and utilization of health centers. Research conducted in the village of Kima Bajo can be seen that knowledge is related to the use of health center because only a small proportion does not utilize health center, because the community, in general, has been able to obtain knowledge about health through health education conducted by health workers in a health center.

Knowledge is the result of knowing and this happens after people have sensed a certain object. The process of seeing, witnessing, experiencing, or being taught greatly determines the occurrence of knowledge in a person. Knowledge is a very important factor in the formation of one's actions (over behavior). Because if someone does not know about an object, then the object will not be attractive to someone. Likewise, the use of health services, especially Puskesmas. One's knowledge can be obtained both from experience and from the educational bench which is the basis of one's insight and the means to make it easier for someone who receives new knowledge and behaviors the level of formal education one has ever acquired will increase knowledge of his reasoning power. Knowledge about health center can influence people's behavior in utilizing health center services to check their health. Knowledge is a very important role in providing insight into the form of attitude, which will then be followed by actions in choosing health services that are believed to be capable of. The level of knowledge influences the use of health center, if the community does not know about the benefits of the health center, then the community sees it as not important to utilize the health services provided (Karman and Saptaputra, 2017).

Table 11. Effect of Facilities with Utilization of Health Services at Tamalanrea Health Center

\begin{tabular}{|c|c|c|c|c|c|c|c|}
\hline \multirow{3}{*}{ Facilities } & \multicolumn{4}{|c|}{ Utilization of health services } & \multirow{2}{*}{\multicolumn{2}{|c|}{ Amount }} & \multirow{3}{*}{$p$} \\
\hline & \multicolumn{2}{|c|}{$\begin{array}{c}\text { To take } \\
\text { advantage of }\end{array}$} & \multicolumn{2}{|c|}{ Haven't utilized } & & & \\
\hline & $\mathrm{n}$ & $\%$ & n & $\%$ & $\mathrm{n}$ & $\%$ & \\
\hline Complete & 22 & 64,7 & 12 & 35,3 & 34 & 100,0 & 0,015 \\
\hline Less complete & 23 & 92,0 & 2 & 8,0 & 25 & 100,0 & \\
\hline Amount & 45 & 76,3 & 14 & 23,7 & 59 & 100,0 & \\
\hline
\end{tabular}

Source: primary data that has been processed, 2019 
Table 11 shows that out of 34 respondents who stated complete facilities as many as 22 respondents (64.7\%) utilized health services in the high category and as many as 12 respondents (35.5\%) utilized health services in the low category. Whereas of the 25 respondents who stated the facilities were incomplete as many as 23 respondents (92.0\%) with a high category in utilizing health services and as many as 2 respondents $(8.0 \%)$ utilized health services with a low category at the Tamalanrea Health Center. Statistical test results obtained the value of $\mathrm{p}=0.015$ because the value of $\mathrm{p}<\alpha=0.015<0.05$ then $\mathrm{Ho}$ is rejected, this means that there is a relationship between facility variables and the utilization of health services in Tamalanrea Health Center.

The results of this study are in line with the results of research conducted by (Wulandari, 2015) which shows the chi-square statistical analysis obtained the value of $\mathrm{P}=0.013$ means that $\mathrm{Ho}$ was rejected $\mathrm{Ha}$ accepted. This means there is a relationship between facilities and infrastructure with the utilization of health services by the Langara community. Also, research conducted by Adam (2014) stated that facilities (44.2\%) and the good attitude of officers (46.7\%) had a significant influence. The better facilities and attitudes of officers, the higher the level of utilization of health services in Indonesia Rural Communities in Southern Nigeria (Adam and Awunor, 2014). But different from the research conducted by (Tasya and Andriany, 2016) based on the results of the chi-square test obtained $\mathrm{p}$-value $=$ 0.648 ( $p>0.05$ ) which means that health facilities do not have a significant relationship with the utilization of dental and oral health services by patients at the Dental and Oral Hospital (RSGM) of Syiah Kuala University, Banda Aceh. If the patient feels comfortable with services in a hospital, then comfort will affect patient satisfaction, thus encouraging patients to come for treatment again.

Trust in this study relates to interactions between staff and patients, how much trust is needed in the utilization of health services. One of the factors that influence the utilization of health services is the level of trust in the health services provided. A good relationship between officers and patients will lead to trust and credibility by respecting what can be seen through acceptance, trust, empathy, keeping secrets, respecting and giving attention to patients.

Table 12. Influence of Trust with Utilization of Health Services at Tamalanrea Health Center

\begin{tabular}{|c|c|c|c|c|c|c|c|}
\hline \multirow{3}{*}{ Trust } & \multicolumn{4}{|c|}{ Utilization of health services } & \multirow{2}{*}{\multicolumn{2}{|c|}{ Amount }} & \multirow{3}{*}{$p$} \\
\hline & \multicolumn{2}{|c|}{$\begin{array}{c}\text { To take } \\
\text { advantage of }\end{array}$} & \multicolumn{2}{|c|}{ Haven't utilized } & & & \\
\hline & $\mathbf{n}$ & $\%$ & $\mathbf{n}$ & $\%$ & $\mathbf{n}$ & $\%$ & \\
\hline Believe & 19 & 61,3 & 12 & 38,7 & 31 & 100,0 & 0,004 \\
\hline Lack of trust & 26 & 92,9 & 2 & 7,1 & 28 & 100,0 & \\
\hline amount & 42 & 76,3 & 58 & 23,7 & 59 & 100,0 & \\
\hline
\end{tabular}

Source: primary data that has been processed, 2019

Table 12 shows that of the 31 respondents who stated they believed as many as 19 respondents (61.3\%) who had utilized health services and as many as 12 respondents (38.7\%) who had not utilized health services. While of the 28 respondents who stated they lacked confidence, 26 respondents (92.9\%) had 
used health services and 2 respondents (7.1\%) had not utilized health services at the Tamalanrea Health Center. This result is supported by research conducted by Ndikom (2012), which conducted a qualitative study of awareness and perceptions of the use of cervical cancer screening services among women in Ibadan, obtained the result that the belief to be at risk of cervical cancer would encourage them to screen, they also believed that it is important as for other diseases will help in early detection and treatment (Agustina, 2019). The results of research conducted by (Pratiwi and Wahyono, 2017) with statistical tests using chi-square showed the variable of trust in the disease has a significant relationship with the utilization of health services at the Unnes Health Center $(p=0.009)$. Based on the results of multivariate analysis, it shows that belief in disease affects students in the utilization of health services at the Unnes Health Center $(\mathrm{p}=0.007$; $\exp (\mathrm{B})=21,064$; $95 \% \mathrm{CI}=2,331-190,349)$. The interpretation of the logistic regression test is that respondents with a high level of trust in disputes are 21 times more likely to utilize health services at the Unnes Health Center than respondents with low trust in disease. The disease confidence variable is the variable that gives the most dominant influence in this study.

In contrast to the results of research conducted (Masita et al., 2017), the $\rho$ value of 0.233 means $\rho$ value $>\alpha(0.05)$ so that it can be concluded that Ho is accepted, meaning that there is no relationship between belief in health services and the utilization of health services in Tanailadu Village community in the Kadapa-Napa Community Health Center in Mawasangka District, Buton Tengah District in 2015. Relevant research results were also conducted by (Rachmawati and Amir, 2014), factors related to the utilization of health services in Tamanlanrea Public Health Center in Makassar City in 2014 which stated that there is no relationship between predisposing factors (beliefs) with the patient's decision to use the service. Based on the interview results from the questionnaire questions on the item "If the doctor did not come, do you entrust nurses to treat you?" Get an answer as much as $50.8 \%$ do not trust the nurse when the doctor did not come. Most of the reasons immigrants rely more on the ability of a doctor than a nurse, they do not believe that nurses can treat or understand the pain they suffer. So if they use health services they don't want to be examined if they are not a doctor.

\section{IV.CONCLUSION}

Based on the results of research on the factors that influence immigrant patients on the utilization of health services in Tamalanrea Health Center, conclusions can be drawn as follows: (1) Gender and age do not have an influence on the utilization of health services, sex has an influence on the utilization of health services in Tamalanrea Health Center and (2) There is an influence of facilities, and trust in the use of health services with the respective $\mathrm{p}$-value: facilities $\mathrm{p}=0.015$ and trust $\mathrm{p}=0.004$. While knowledge has a value of $\mathrm{p}=0.665$ so that it does not influence the utilization of health services at the Tamalanrea Health Center.

The suggestions in this study are (1) Suggestions for Tamalanrea Public Health Center agencies that are to keep maintaining and further improving health services and health promotion in each community house of immigrants so that they are more interested and more entrusted to utilize health services when falling ill or have a complaint of ordinary illness and (2) Suggestions to the detention center to help promote and convince immigrants or refugees abroad that first-rate health services are able to provide the best health services. 


\section{REFERENCES}

[1]. Abdullah, A., Sjattar, E. L. \& Kadir, A. R. 2017. Faktor Penyebab Terjadinya Penurunan Jumlah Kunjungan Peserta Program Pengelolaan Penyakit Kronis (Prolanis) di Puskesmas Minasa Upa Kota Makassar. Jurnal Ilmiah Kesehatan Diagnosis, 11, 382-387.

[2]. Agustina, S. 2019. Persepsi Sakit, Pengetahuan dan Kepuasan dengan Pemanfaatan Pelayanan Kesehatan di Puskesmas. HIGEIA (Journal of Public Health Research and Development), 3, 274-285.

[3]. Damayanti, M., Jati, S. P. \& Arso, S. P. 2017. Analisis Permintaan Masyarakat Terhadap Pelayanan Rawat Jalan Rumah Sakit Umum Daerah Dr. R. Soetijono Blora. Jurnal Kesehatan Masyarakat (e-Journal), 5, 85-94.

[4]. Dong, G. N. 2016. Earnings management in US hospitals. Journal of health and human services administration, 41-71.

[5]. Indar, 2017. Etikolegal dalam Pelayanan Kesehatan. Yogyakarta: Pustaka Pelajar.

[6]. Karman, K. \& Saptaputra, S. 2017. FaktorFaktor Yang Berhubungan Dengan Pemanfaatan Pelayanan Kesehatan Bagi Masyarakat Pesisir Di Desa Bungin Permai Kecamatan Tinanggea kabupaten Konawe Selatan Tahun 2016. Jurnal Ilmiah Mahasiswa Kesehatan Masyarakat, 1.

[7]. Marnah, M., Husaini, H. \& Ilmi, B. 2016. Analisis Perilaku Masyarakat dalam Pemanfaatan Pelayanan Kesehatan Peserta Program Keluarga Harapan (PKH) di Kecamatan Paminggir. Jurnal Berkala Kesehatan, 1, 130-138.

[8]. Notoatmodjo, S. 2003. Pendidikan dan perilaku kesehatan. Jakarta: rineka cipta, 16, 15-49.

[9]. Nst, E. D. 2018. Peranan International Organization For Migration (IOM) Dalam
Menangani Permasalahan Refugees (Pengungsi) Rohingya Di Indonesia. Jurnal Power in International Relations (PIR), 2, 70-81.

[10]. Pratiwi, A. \& Wahyono, B. 2017. The Pemanfaatan Pusat Layanan Kesehatan (Puslakes) Universitas Negeri Semarang. HIGEIA (Journal of Public Health Research and Development), 1, 49-60.

[11]. Rachmawati, D. \& Amir, M. 2014. Faktor Yang Berhubungan Dengan Pemanfaatan Pelayanan Kesehatan Di Puskesmas Tamalanrea Kota Makassar.

[12]. Rumengan, D. S., Umboh, J. \& Kandou, G. 2015. Faktor-faktor yang berhubungan dengan pemanfaatan pelayanan kesehatan pada peserta BPJS kesehatan di Puskesmas Paniki Bawah Kecamatan Mapanget Kota Manado. Jikmu, 5.

[13]. Singal, H. I., Kandou, G. D. \& Rumayar, A. A. 2019. Hubungan Antara Pengetahuan, Sikap Dan Pendapatan Dengan Pemanfaatan Puskesmas Oleh Masyarakat Desa Kima Bajo Kecamatan Wori. Kesmas, 7.

[14]. Tasya, N. \& Andriany, P. 2016. Faktor-Faktor Yang Berhubungan Dengan Pemanfaatan Pelayanan Kesehatan Gigi Dan Mulut di Rumah Sakit Gigi Dan Mulut (RSGM) Universitas Syiah Kuala Banda Aceh. Journal Caninus Dentistry, 1, 54-62.

[15]. Wahyuni, N. S. 2012. Faktor-Faktor yang Berhubungan dengan Pemanfaatan Pelayanan Kesehatan di Puskesmas Sumber Rejo Kota Balikpapan Provinsi Kalimantan Timur Tahun 2012. AWSAccessKeyId $=$ AKIAIWOW YYGZ2Y53UL3A\&Expires=

1533197103\&Signature $=$ Ad\% 2F2b1vl0CA 1EUaN\% 2Fieq8SzA1U4\% 3D\&responsecontentdisposition= inline $\%$ 3B\% 20filename $\%$ 3DFile_pemanfaatan kesehatan_di_puskesmas. pdf. 
[16]. Wibowo, W., Su'udi, A. \& Sahir, M. 2019. Pengaruh Perubahan Iklim Terhadap Insiden Malaria Di Wilayah Keja Dinas Kesehatan Kabupaten Gowa Propinsi Sulawesi Selatan Tahun 2017. Media Kesehatan Politeknik Kesehatan Makassar, 14, 60-65.

[17]. Yang, P. Q. \& Hwang, S. H. 2016. Explaining immigrant health service utilization: a theoretical framework. Sage Open, 6, 2158244016648137.

[18]. Yaya, S., Bishwajit, G. \& Ekholuenetale, M. 2017. Factors associated with the utilization of institutional delivery services in Bangladesh. PLoS One, 12, e0171573.

\section{Cite this article as :}

Nurul Qalbi R, Indar, Rahmatiah, "Factors Affecting Immigrant Patients Against Utilization of Health Services at Tamalanrea Health Center", International Journal of Scientific Research in Science and Technology (IJSRST), Online ISSN : 2395-602X, Print ISSN : 2395-6011, Volume 6 Issue 5, pp. 188-199, September-October 2019. Available at doi : https://doi.org/10.32628/IJSRST196521

Journal URL : http://ijsrst.com/IJSRST196521 